\title{
Evaluating the Thermodynamics and Kinetics of Production of Caustic Soda from Brine
}

\author{
Awajiogak A. Ujile1", Amesi Dirinna1', Joshua Konne² \\ ${ }^{1}$ Department of Chemical/Petrochemical Engineering, Rivers State University of Science \& Technology, Port Harcourt, Nigeria \\ ${ }^{2}$ Department of Chemistry, Rivers State University of Science \& Technology, Port Harcourt, Nigeria \\ Email: *ujile.awajiogak@ust.edu.ng, *ogakujile@yahoo.com
}

How to cite this paper: Ujile, A.A., Dirinna, A. and Konne, J. (2018) Evaluating the Thermodynamics and Kinetics of Production of Caustic Soda from Brine. Journal of Modern Physics, 9, 99-111. https://doi.org/10.4236/jmp.2018.92007

Received: October 9, 2017

Accepted: January 16, 2018

Published: January 19, 2018

Copyright () 2018 by authors and Scientific Research Publishing Inc. This work is licensed under the Creative Commons Attribution International License (CC BY 4.0).

http://creativecommons.org/licenses/by/4.0/

(c) (i) Open Access

\begin{abstract}
This work is detailed towards ascertaining the thermodynamics and kinetics considerations for the production of caustic soda from brine and soda ash. The thermodynamics considers the Gibbs free energy; which is the minimum electrical work that must be supplied to an electric cell to drive the electrochemical reactions and its relationship with other thermodynamic parameters. The kinetics aspect of this research deduces the reaction rate equations and also predicts via feasible calculations the rate of the reaction, rate constant and order of the reaction. The examination of the thermodynamic analysis shows that the reaction is exothermic, positive value of entropy indicates that there is intrinsic energy which can be converted into work by a perfect electrolytic reaction process. The work determines the extent and the rate of the production process of caustic soda production and as such a pilot plant production of caustic soda from naturally occurring seawater via the diaphragm cell may be developed. The results obtained have shown that the cell potential using the Nerst equation for the production of optimum product caustic soda are: $E=$ 0.5232 volt and the reaction is of second order. The rate of the reaction $r=6.264 \times 10^{-12} \mathrm{~mol} \cdot \mathrm{cm}^{-2} \cdot \mathrm{s}^{-1}$ and the rate constant

$K_{2}=9.2591 \times 10^{-5} \mathrm{~cm} \cdot \mathrm{s}^{-1}$.
\end{abstract}

\section{Keywords}

Rate Constant, Entropy, Enthalpy, Gibbs Energy, Soda Ash, Constituent Ions

\section{Introduction}

Electrochemical processes provide the only commercially viable means for the production of caustic soda, chlorine and some chemical products [1]. Chlorine and caustic soda are involved directly or indirectly in the manufacture of about 
70 percent of all chemical products [2].

According to Ohm [2] and Bergner [3] a typical world-scale chlor-alkali electrolysis plant produces above 1000 tons of caustic soda a day, consuming a shipload of salt (about 1700 tons) and enough electricity. Furthermore, the process chemistry of the chlor-alkali electrolytic production of caustic soda is simple to understand, the design and operational issues are vastly complex [4] [5]. Presently, the raw material required for the production of caustic soda is rock salt. This has to be imported from West Indies, Australia, or Europe initially until such a time that local supply of rock salt is feasible or the government puts in place the necessary enabling environment for the development and sustenance of industries in the country.

During the industrial production of caustic soda, chlorine is also obtained simultaneously by the electrolysis of brine (salt solution). The electrolytic dissociation of brine is carried out in a specially designed cell. The final products are caustic soda, chlorine and hydrogen. The caustic soda plant consists primarily of a huge assemblage of unit cells. The design and construction of the unit cells remain a closely guarded secret of the manufacturers which fact accounts for the reluctance of plant manufacturers to supply caustic soda plants to foreign countries. Design methodology for parametric study and thermodynamic performance evaluation of natural gas process plant has been developed by Ujile and Amesi [6]. The results obtained show the comparison of the coefficient of performance, compression ratio, isentropic work, actual work, electrical power requirements, cooling water consumption in intercoolers, compressor power output, compressor capacity, isentropic, volumetric and mechanical efficiency of the two-stage refrigeration unit with a flash gas economizer and these were compared with the designed specifications. However, the thermodynamic process for the electrolysis of brine has not been established. Sandler [7] proposed that electrical work can be obtained from controlled chemical reactions, but not if the reaction is allowed to proceed simultaneously. It is on this basis that cell potential is developed. Furthermore Nerst equation is used to find the cell potential at any moment or conditions other than standard state [8].

\subsection{Thermodynamics Considerations}

The change in Gibbs free energy, $\Delta G$ is the minimum electrical work that must be supplied to an electric cell to drive the electrochemical reaction [9].

$$
\Delta G=-n F E^{o}
$$

Besides, free energy and equilibrium constant are related by the following equations:

$$
\Delta G=\Delta G^{0}+R T \ln Q
$$

The change in free energy is defined as the change in enthalpy as follows [10] [11] [12]:

$$
G=H-T S
$$


Transforming the equation from ideal system to real system, the concept of fugacity and activity are introduced [13]. This could be achieved by considering the free energy in a differential form as:

$$
\mathrm{d} G=-S \mathrm{~d} T+V \mathrm{~d} P
$$

Equation (4) can be transposed with other relations into Equation (5)

$$
\begin{aligned}
& G=G^{0}+n R T \ln \frac{f}{f^{0}} \\
& G=G^{0}+n R T \ln a
\end{aligned}
$$

\subsection{Kinetics Considerations}

The kinetics aspect of the work was based on the fact that electrochemical reaction comprises the transfer of electrons between an electronically conducting electrode and an ionically conducting electrolyte.

Rate of electrochemical reactions: These are heterogeneous chemical reactions whose activation energies can be altered by varying the potential difference. It differs from other heterogeneous reactions in that electron transfer occurs between the electrodes and the reactants during one step of the overall process [14]. The reaction proceeds at different rates with the variation of potential difference across the interface. The similarity of electrochemical reactions with heterogeneous reactions is that it involves the transfer of complex ions, hydrated cations and anions across the interface. A charge transfer across such an interface implies chemical transformation. The rate of such Faraday's process can be measured by the current passed or produced as the case may be.

Considering the passage of a current of $(i)$ amperes for $(t)$ second to cause the decomposition (dissolution) of ( $W$ ) grams of a substance of equivalent weight $E$ and molecular weight, $M$ (stated from Faraday's laws of electrolysis) we obtained Equation (6) [12].

$$
m=I \times t \times E
$$

Also from second law it is deduced that;

$$
M \propto \frac{I}{F}
$$

where $F=$ Faraday's constant or quantity of electricity called Faraday.

Note; one Faraday discharges one mole of ions of a univalent element such as hydrogen, sodium, silver and chlorine [15].

Combining Equations ((6) and (7)) we have,

$$
W=\frac{I E t}{F}
$$

where; $E \times n=M \quad$ ( $n$ is the number of electrons involve in the electrode reaction). $I$ is the current density.

Equation (8) becomes

$$
I=\frac{m F}{(M / n) t}=\frac{w n f}{m t}
$$


where; $n f=$ (coulomb), $\frac{W}{m t}(\mathrm{~mol} / \mathrm{s})$.

If the rate in $\mathrm{mol} / \mathrm{s}$ is expressed as $r$, the above equation can be written as

$$
I=n F r
$$

Since electrode reactions are heterogeneous, the rate must be expressed as the number of moles per unit area (c) per unit time [14].

Example is mole $\mathrm{cm}^{-2} \mathrm{~S}^{-1}$. This is achieved by dividing both sides of Equation (10) by the area $(A)$ of the electrode

$$
\frac{1}{A}=\frac{n F r}{A}=\frac{n F C}{t}
$$

where $C=\frac{W}{M A}$

$$
I=n F r=\frac{n F C}{t}
$$

Thus, it is seen that current density is directly proportional to the rate of an electrochemical reaction.

For a first order electrochemical reaction with respect to a reactant, applying Equation (12)

$$
r=K_{1} C=\frac{i}{n F}=\frac{n F C}{t} \times \frac{1}{n F}=\frac{C}{t}
$$

where $K_{1}$ is the first order rate constant for the electrochemical reaction. The units of $K_{1}$ depend on the units of concentration as shown below. When concentration $C$ is used the unit of $K_{1}$ will be $\mathrm{S}^{-1}$ irrespective of $C$ being per $\mathrm{m}^{2}$, per $\mathrm{dm}^{2}$ or $\mathrm{cm}^{2}$ [14].

Considering the reaction mechanism of brine (Sea water), we take the overall reaction as:

$$
2 \mathrm{Na}^{+}+\underset{\text { (aq) }}{\mathrm{Cl}^{-}}+\underset{(\mathrm{L})}{2 \mathrm{H}_{2} \mathrm{O}} \rightarrow 2 \mathrm{Na}_{(\mathrm{aq})}^{+}+2 \mathrm{OH}^{-}+\mathrm{H}_{2(\mathrm{~g})}+\mathrm{Cl}_{2(\mathrm{~g})}
$$

Brine and soda ash give:

$$
\begin{aligned}
& \left\{\mathrm{NaCl}+2 \mathrm{H}_{2} \mathrm{O}\right\}+\mathrm{Na}_{2} \mathrm{CO}_{3} \rightarrow 3 \mathrm{NaOH}+\frac{1}{2} \mathrm{Cl}_{2}+\frac{1}{2} \mathrm{H}_{2}+\mathrm{CO}_{2} \\
& \text { Brine }+ \text { soda ash }
\end{aligned}
$$

Assuming a pseudo homogenous reaction, we can deduce that our reaction is a second order reaction;

$$
r_{\mathrm{NaOH}}=K C_{\mathrm{NaCl}}^{2}
$$

Note: pseudo-order reactions are reactions whose actual order is different from that expected using rate law expression [16].

From the above reaction assuming pseudo-second order implies that excess of reactant $\mathrm{B}\left(\mathrm{H}_{2} \mathrm{O}\right)$ was used such that its concentration remains constant all through the reaction [17]. 


\subsection{Limitations of Other Works}

Although the research above gave a proper analysis on the make-up of a membrane cell which is synonymous to a diaphragm cell and also considered few thermodynamics and kinetics parameters. The following limitations were noted:

- Except the Gibbs free energy, no other thermodynamic parameter was considered (lack of broader knowledge of other thermodynamic parameters related to electrochemical cell).

- The kinetics of the reaction was not also given in details as properties such as rate constant, rate of the reaction and order of the reaction were not considered.

- The source of the brine used whether natural (sea water) or dissolved salt solution was not stated.

The aim of this work therefore involves the thermodynamics and kinetics analysis of caustic soda production from sea water and soda ash. Limitations of other works are considered to establish conditions for high yield of caustic soda production from kinetics and thermodynamics.

\section{Material and Methods}

\subsection{Materials}

The necessary materials used for the work are as follows: A bath, Carbon graphite (anode), Stainless steel (cathode), Permeable diaphragm (asbestos), Ammeter, Voltmeter, Electric cable, Sea water (brine) obtained from Andoni estuary, (Atlantic Ocean), Converter.

Electrolytic cell (diaphragm electrolytic cell) which comprises of the components listed above is shown in Figure 1.

\subsection{Experimental Set-Up}

The experimental set-up consists of electrolytic cell with anode and cathode compartments.

\section{Connection of the Electrolytic Cell}

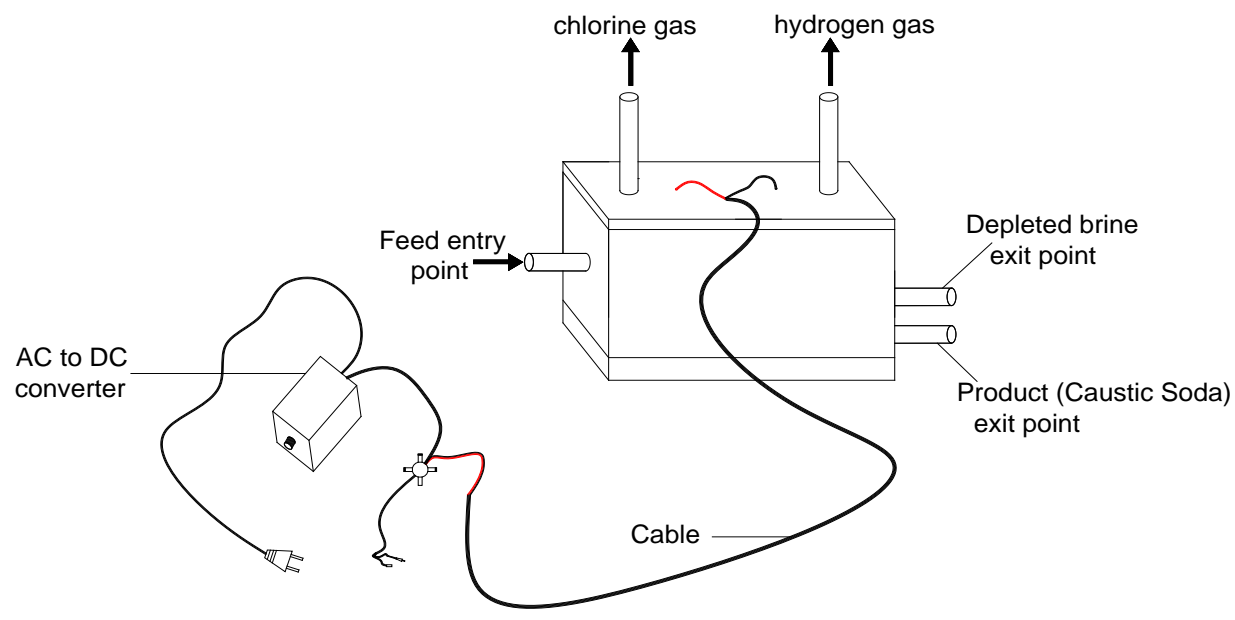

Figure 1. Schematic diagram of experimental set-up. 


\subsection{Methodology for Caustic Soda Production}

The method used for the production of caustic soda was the electrolysis of brine with the use of diaphragm electrolytic cell as shown in Figure 1. In this method, the characterization of the seawater was carried out and the salinity, density and $\mathrm{pH}$ of the feedstock (sea water) were first ascertained.

The seawater was poured into the beaker and the portable $\mathrm{pH}$ meter was dipped inside the beaker containing brine where its reading was noted. The $\mathrm{pH}$ of the seawater was 7.4

An alternating current to direct current converter with an input voltage of 220 $\mathrm{V}$ and a varying voltage of $3,4.5,6,7.5,9$ and 12 volts with a constant current of $1000 \mathrm{~mA}$ was used to switch power to the diaphragm cell. At 3 volts, 4 liters of the feed (Sea Water) was charged into the diaphragm cell through the entry point at the anode compartment with a constant temperature of $28^{\circ} \mathrm{C}$ and after 3 hours, the product (caustic soda) was withdrawn from the exit point at the cathode compartment below the depleted brine exit point. The depleted brine was withdrawn. During this process, hydrogen gas evolves and left the cell through the opening on the cork at the cathode (stainless steel). Chlorine gas also evolves and exits the cell through the opening on the cork at the anode (graphite) compartment. The density of the product (caustic soda) produced was calculated. This process was repeated for various voltages such as, 6 volts, 7.5 volts, 9 volts and 12 volts and their various densities were measured (see Figure 2 for the laboratory set-up).

The researchers decided to introduce soda ash to the process stream and Equation (17) was obtained. This is to enhance the concentration of the caustic soda formed/recovered. Common ion effect influences ionic strength of electrolytes. Therefore this work involves the addition of soda ash, to enhance the yield and strength of caustic soda obtained.

$$
\begin{gathered}
\mathrm{NaCl} \rightarrow \mathrm{Na}^{+}+\mathrm{Cl}^{-} \\
\mathrm{Na}_{2} \mathrm{CO}_{3} \rightarrow 2 \mathrm{Na}^{+}+\mathrm{CO}_{3}^{-}
\end{gathered}
$$

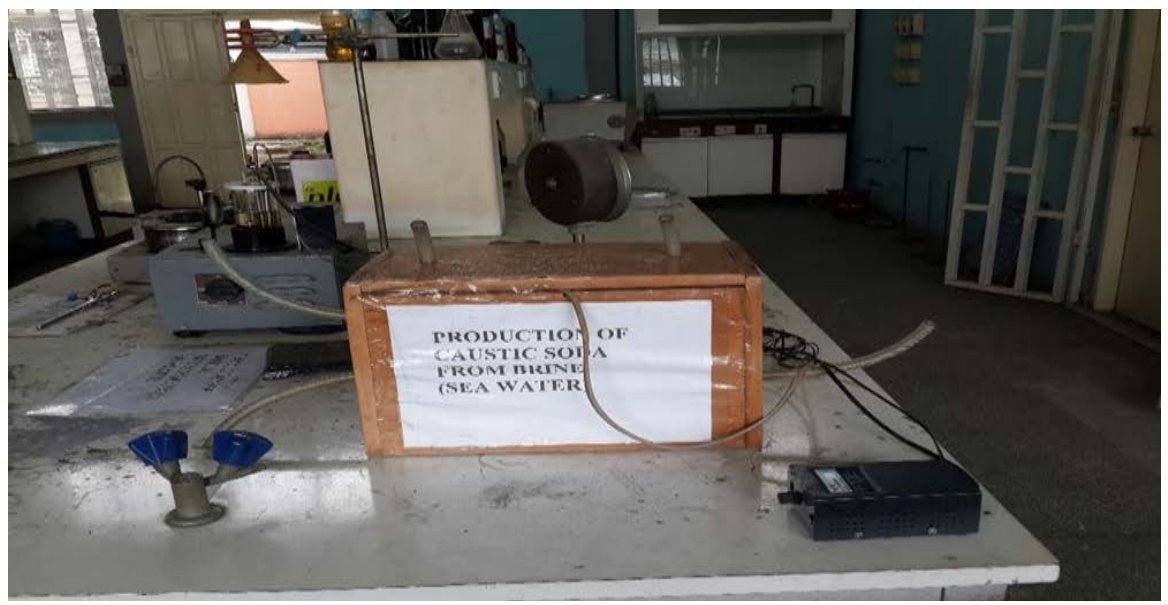

Figure 2. Diagram for the experimental set-up, Chemical/Petrochemical laboratory R.S.U.S.T. 
The final concentration of $\mathrm{Na}^{+}$has contributions from $\mathrm{NaCl}$ and $\mathrm{Na}_{2} \mathrm{CO}_{3}$. In the presence of a second source of $\mathrm{Na}^{+}$, salt will be less soluble if one of its constituent ions is already present in the solution [18]. It is on this phenomenon that this present work was carried out.

$$
\begin{aligned}
& \left\{\mathrm{NaCl}+2 \mathrm{H}_{2} \mathrm{O}\right\}+\mathrm{Na}_{2} \mathrm{CO}_{3} \rightarrow 3 \mathrm{NaOH}+\frac{1}{2} \mathrm{Cl}_{2}+\frac{1}{2} \mathrm{H}_{2}+\mathrm{CO}_{2} \\
& \text { Brine }+ \text { soda ash }
\end{aligned}
$$

It has been stated by one of the authors that in most chemical engineering processes raw materials, intermediate and semi- finished products (in liquid/ gaseous form) move either by gravity and or expenditure of energy from one compartment to the other for quality control purposes and to maintain product specifications [19]. This was applied in this work.

\section{Results and Discussions}

The Nerst equation was applied with the use of optimum values of feed and products. The details of the overall reaction and calculations are shown in Appendix 1.

The sample of free energy calculations is shown in Appendix 2.

The values of the voltages applied and the corresponding yields/concentrations of caustic soda obtained are shown in Table 1 and Figure 3.

$\Delta G$ represents the free energy change. Free Energy change is a combination of enthalpy change, entropy change, and temperature that can be used to determine whether a process is spontaneous or nonspontaneous. It is used to predict reaction's spontaneity of a reaction with constant temperature and pressure.

Solving for rate of reaction and rate constant using values of the optimum feed (dehydrated brine) and product (caustic soda produced from the brine at 12 $\mathrm{V}$ ) as shown in appendix we obtained the order of the reaction.

The salinity (salt concentration) value of our brine is $19.9 \mathrm{~g} /$ liter (obtained from salinity test for dehydrated brine below) and the time that was used for the electrolysis of the optimum product was 3 hours which is equivalent to 10,800 seconds.

Table 1. Relationship between different mixtures and increment in the amount of soda ash, voltage and concentration.

\begin{tabular}{ccccc}
\hline & \multicolumn{4}{c}{ Percentage concentration (\%) } \\
\cline { 2 - 5 } Voltage (V) & Brine only Soda ash + brine $\begin{array}{c}\text { Soda ash/water solution } \\
\text { + brine }\end{array}$ & $\begin{array}{c}\text { 10\% increment of soda ash } \\
\text { in soda ash/water solution }\end{array}$ \\
\hline 3 & 0.024 & 0.224 & 0.480 & 0.614 \\
4.5 & 0.032 & 0.500 & 0.520 & 0.668 \\
6 & 0.056 & 0.512 & 0.536 & 0.696 \\
7.5 & 0.072 & 0.536 & 0.561 & 0.720 \\
9 & 0.092 & 0.560 & 0.584 & 0.744 \\
12 & 0.104 & 0.586 & 0.624 & 0.755 \\
\hline
\end{tabular}




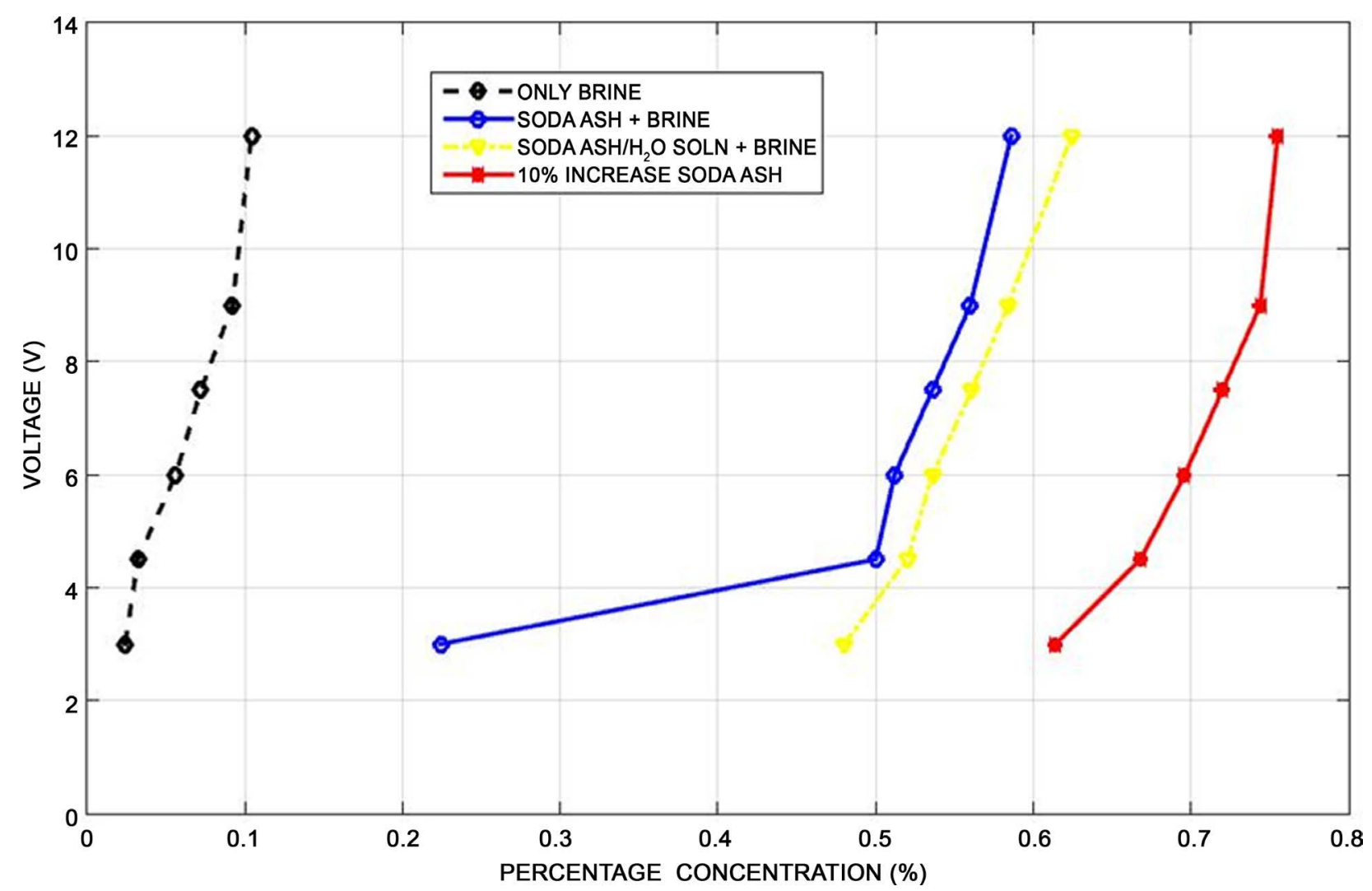

Figure 3. Graph of voltage against percentage concentration of $\mathrm{NaOH}$ with varied quantity of soda ash.

Using Equation (16) to calculate rate of reaction for the second order reaction and converting the mass concentration to molar concentration we have;

Molar concentration of brine $=$ mass concentration of dehydrated brine $/$ molar mass of dehydrated brine $\left(\mathrm{NaCl}+\mathrm{H}_{2} \mathrm{O}\right)$

\section{Anode Reaction}

$$
2 \underset{(\text { aq })}{\mathrm{Cl}^{-}}-2 \mathrm{e}^{-} \rightarrow \mathrm{Cl}_{2(\mathrm{~g})}
$$

\section{Cathode Reaction}

$$
\begin{gathered}
\mathrm{H}_{2} \mathrm{O}_{(1)}+2 \mathrm{e}^{-} \rightarrow \mathrm{H}_{2(\mathrm{~g})}+\mathrm{OH}_{(\mathrm{aq})}^{-} \\
\mathrm{Na}^{+}+\mathrm{OH}^{-} \rightarrow \mathrm{NaOH} \text { (desired product) }
\end{gathered}
$$

The sodium ion produced are not liberated first as metal through the electrode due to its higher potential discharge compare to hydrogen, but will be in solution form with the hydroxyl ion in the cathode department and it is concentrated by evaporation before collection.

The cell potential using the Nerst equation for the production of optimum product (caustic soda produced at $12 \mathrm{~V}$ using the dehydrated brine), $E=0.5231$ volt . The reaction is of second order. The rate of the reaction $r=6.264 \times 10^{-12} \mathrm{~mol} \cdot \mathrm{cm}^{-2} \cdot \mathrm{s}^{-1}$ and the rate constant $K_{2}=9.2591 \times 10^{-5} \mathrm{~cm} \cdot \mathrm{s}^{-1}$.

From the thermodynamics properties and result obtained from Gibbs free energy equation the negative sign indicated that, the work was done by the cell 
on the surrounding as proposed by (Stanley, 1999), [20] which implies an exothermic reaction and an energy (electrical) consuming reaction.

From Figure 3, it is clear that the concentration of caustic soda produced increases with increase in voltage, suggesting that maximum concentration of caustic soda is achieved by operating the voltage of the process at its peak. Also, viewing the graph from left to right, shows that the percentage of caustic soda in the product increased with increase in the quantity of soda ash added, suggesting that there was an increment in the amount of sodium ions present to react with the hydroxide ions dissociated from the water in the solution, thereby yielding an increased concentration of the product. The graph also indicates that soda ash/water solution gave high yield than only brine and mixture of brine and soda ash, this may be due to complete dissolution of soda ash in water. This deviation on the graph either from brine to brine + soda ash indicates the quantity of soda ash added during the process. The graphs which yield similar experimental results obtained from the study of this production type using a solar powered asbestos diaphragm cell indicating that higher voltage give a higher percentage concentration.

\section{Conclusions}

The results obtained have shown that the cell potential using the Nerst equation for the production of optimum product caustic soda are $E=0.5232$ and the reaction is second order.

The yield of the desired product (caustic soda) increased not only with increased voltage, but also with increased mass of soda ash added to the brine solution. The final concentration of $\mathrm{Na}^{+}$has contributions from $\mathrm{NaCl}$ and $\mathrm{Na}_{2} \mathrm{CO}_{3}$. In the presence of a second source of $\mathrm{Na}^{+}$, salt was less soluble as one of its constituent ions was already present in the solution.

The thermodynamic analysis based on the change in the Gibbs free energy of the system that work was done by the cell on the surrounding which implies that the system requires higher electrical energy for its effectiveness. The highlight of this work is shown in Appendix 3.

\section{Recommendations}

- We recommend that in the manufacture or production of a highly concentrated caustic soda by the process of electrolysis, highly saturated brine should be used and the voltage of the system should be kept at $12 \mathrm{~V}$ and above for maximum results.

- Further studies on the use of alternative membrane instead of asbestos as the latter are not environmentally friendly but produces high quality/purity caustic soda. Asbestos membrane allows only the passage of the $\mathrm{Na}^{+}$ion from the cathode to the anode of the cell which gives it the advantage over diaphragm cell. The characteristics should be embedded in the new membrane that may be established from further work. 
- The results obtained from this work (cell potential value and second order reaction) should be applied by other researchers to design pilot plant for the production of caustic soda from brine.

\section{Acknowledgements}

The authors appreciate the management of Rivers State University of Science and Technology, technologists of the Chemical/Petrochemical Engineering laboratory, Ven. Chukwuigwe and Mr. Eno Okon for their support.

The authors declare that there is no conflict of interest regarding the publication of this paper.

\section{References}

[1] Alkire, R.C. and Braatz, R.D. (2004) American Institute of Chemical Engineers Journal, 50, 2000-2007. https://doi.org/10.1002/aic.10308

[2] Ohm, C. (2007) Innovative Chlorine Production-Increasing Energy Efficiency. http://www.press.bayer.com/baynews.nsf/id/F9D7D3.PP.1-10

[3] Bergner, D. (1982) Journal of Applied Electrochemistry, 12, 631-644. https://doi.org/10.1007/BF00617483

[4] Olufemi, B.A., Ozowe, W.O. and Komolafe, O.O. (2011) ARPN Journal of Engineering and Applied Sciences, 6, 49-54.

[5] Babatope, A. and Monisola, T. (2012) Journal of Institute of Electrical Electronic Engineering, 12.

[6] Ujile, A.A and Amesi, D.C. (2014) Journal of Thermodynamics, 2014, Article ID: 863408. https://doi.org/10.1155/2014/863408

[7] Sandler, S.I. (2006) Chemical, Biochemical and Engineering Thermodynamics. Wiley Asia Student Edition Fourth Edition.

[8] Fine, L.W., Beal, H. and Stuehr, J. (1999) Chemistry for Scientists and Engineers (Preliminary Paperback Version of the New Edition). Saunders College Publishing, Philadelphia.

[9] Levine, I.N. (1995) Physical Chemistry In: Science. 6th Edition, McGraw-Hill, Washington DC, $989 \mathrm{p}$.

[10] Cengel, Y.A. and Boles, M.A. (2002) Thermodynamics: An Engineering Approach. 4th Edition, McGraw Hill Book Company, New York.

[11] Roy, G.K. (2013) Solved Examples in Chemical Engineering. 10th Edition, Khanna Publishers, New Delhi.

[12] Rosenberg, J.L. and Epstein, M.L. (2000) Shaum's Outline of College Chemistry. McGraw-Hill, Inc., Washington DC.

[13] Smith, R. (2005) Choice of Reactor 2-Reactor Condition. John Wiley and Sons, Ltd., Singapore.

[14] Rajaram, J. and Kuriacose, J.C. (1993) Electrochemical Methods Used in Electrode Kinetics, Reaction at Electrode Surface Kinetics and Mechanisms of Chemical Transformation. 3rd Edition, Macmillan Publishers India Ltd., New Delhi.

[15] Ababio, O.Y. (2003) Electrode Potentials, Electrochemical Series, Electrolysis. 3rd Edition, Africana First Publishers Limited, Lagos.

[16] Elearn-Ocean (2010) Introduction to Chemical Kinetics. http://www.elearn-ocean.com/chemical/ce/ 
[17] Coulson and Richardson (1991) Chemical Kinetics and Rate Equations. Vol. 3. Reed Elsevier India Private Ltd., Burlington.

[18] Haris, D.C. (2003) Quantitative Chemical Analysis. 6th Edition, Freeman and Company, New York, p. 105.

[19] Ujile, A.A. (2014) Chemical Engineering Unit Operations, Synthesis and Basic Design Calculations, Vol. 1. Bomn Prints, Ibadan.

[20] Sandler, S.I. (1999) Chemical and Engineering Thermodynamics. 3rd Edition, John Wiley and Sons Inc., Singapore.

\section{Nomenclature}

$\Delta G=$ change in Gibbs free energy

$\Delta G^{0}=$ the standard-state free energy

$a=\operatorname{activity}(\infty)=\frac{f}{f^{o}}$

$E=$ Cell potential $(V)$ under specific conditions

$E^{o}=$ standard electrode potential (Cell potential at standard-state conditions)

$F=$ Faraday's constant, the charge on a mole of electron 96485 (96500) coulomb/ mol or joule/volt-mol

$f=$ fugacity $\left(\mathrm{N} \cdot \mathrm{m}^{2}\right.$ or bar $)$

$\rho=$ fugacity at standard conditions $\left(\mathrm{N} \cdot \mathrm{m}^{2}\right.$ or bar $)$

$H=$ enthalpy

$I=$ the current density, ampere

$\ln Q=$ the natural $\log$ of the reaction quotient.

$\ln Q c=$ the natural log of the reaction quotient at the moment in time

$K=$ the rate of the electrochemical reaction, $\mathrm{mol} \mathrm{S}^{-1}$ per unit area.

$m=$ mass of the substance transferred, $\mathrm{kg}$

$n=$ no of moles of electrons transferred (in the balanced equation)

$n_{a}^{v_{1}}$ products $=$ molar concentration of products

$n_{a}^{v_{1}}$ reactants $=$ molar concentration of reactants

$R=$ the ideal gas constant $(8.314 \mathrm{~J} / \mathrm{mol} \cdot \mathrm{K})$

$R=$ Ideal gas constant $=8.3140 \mathrm{~J} / \mathrm{mol} \cdot \mathrm{K}$

$S=$ entropy

$T=$ the temperature (K)

$T^{\circ}=$ temperature $($ Kelvin $)$, at $25^{\circ} \mathrm{C}\left(298^{\circ}\right)$ 


\section{Appendix 1. The Overall Reaction}

Applying the Nerst equation using the optimum values of feed and product, (i.e.; values of dehydrated brine and caustic soda produced at 12 volt in 3 hours could be obtained.

Number of moles transferred from overall reaction $=2$ moles

Mass of dehydrated brine $=50.7201 \mathrm{~g}$

Volume of brine $=50 \mathrm{ml}$

Molarity of brine $=$ number of moles of brine/volume

Number of moles of brine $=$ mass of brine $/$ molar mass of brine

Molar mass of brine $\left(\mathrm{NaCl}+\mathrm{H}_{2} \mathrm{O}\right)=(23+35.5+2+16)=76.5 \mathrm{~g} / \mathrm{mol}$

Number of mole $=50.7201 \mathrm{~g} / 76.5 \mathrm{~g} / \mathrm{mol}=0.66$ moles

Molarity of brine $=0.66$ moles $/ 50 \mathrm{ml}=0.0132 \mathrm{M}$

Also; for optimum yield of caustic soda (caustic soda at $12 \mathrm{~V}$ )

Mass of caustic soda $=52.64$

Molar mass of caustic soda $(\mathrm{NaOH})=(23+16+1)=40 \mathrm{~g} / \mathrm{mol}$

Number of moles of caustic soda $=52.64 / 40=1.316$ moles

Molarity of caustic soda $=1.316 \mathrm{moles} / 50 \mathrm{ml}=0.0263 \mathrm{M}$

The voltage at the anode at standard state

$$
2 \mathrm{Cl}_{(\text {aq) }}^{-} \rightarrow \mathrm{Cl}_{2(\mathrm{~g})}+2 \mathrm{e}^{-}=1.36 \mathrm{~V}
$$

The voltage at the cathode at standard state

$$
2 \mathrm{H}_{2} \mathrm{O}_{(\mathrm{l})}+2 \mathrm{e}^{-} \rightarrow \mathrm{H}_{2(\mathrm{~g})}+2 \mathrm{OH}_{(\mathrm{aq})}^{-}=-0.828 \text { volt }
$$

Substituting values and applying Nerst equation, Equation (1) becomes;

$$
\begin{gathered}
E=E^{o}+\frac{R T}{n F} \ln \frac{n_{a}^{v_{1}} \text { reactants }}{n_{a}^{v_{1}} \text { products }} \\
E=(1.36-0.828)+\frac{0.02568}{2} \ln \frac{0.0132 M}{0.0263}=0.5231 \text { volt }
\end{gathered}
$$

\section{Appendix 2. Sample Free Energy Calculation at Standard-} State Conditions

$$
2 \mathrm{NaCl}_{(\mathrm{aq})}+2 \mathrm{H}_{2} \mathrm{O}_{(\mathrm{l})} \rightarrow 2 \mathrm{NaOH}_{(\mathrm{aq})}+\mathrm{H}_{2(\mathrm{~g})}+\mathrm{Cl}_{2(\mathrm{~g})}
$$

But with soda ash, we obtain

$$
\begin{aligned}
& \left\{\mathrm{NaCl}+2 \mathrm{H}_{2} \mathrm{O}\right\}+\mathrm{Na}_{2} \mathrm{CO}_{3} \rightarrow 3 \mathrm{NaOH}+\frac{1}{2} \mathrm{Cl}_{2}+\frac{1}{2} \mathrm{H}_{2}+\mathrm{CO}_{2} \\
& \text { Brine + soda ash }
\end{aligned}
$$

Calculating for Gibbs free energy at standard state using standard state values of Enthalpy $\Delta H^{\circ}$, temperature $T$ and Entropy $\Delta S^{\circ}$

$$
\begin{aligned}
\Delta H^{o}= & \sum n H^{0} \text { of products }-\sum m H^{0} \text { of reactact } \\
= & |(1 \mathrm{~mol} \mathrm{NaOH} \times 469.15 \mathrm{~J} / \mathrm{mol})| \\
& -\left(1 \mathrm{~mol} \mathrm{NaCl} \times 407.27 \mathrm{~J} / \mathrm{mol}+\left(1 \mathrm{~mol} \mathrm{H}_{2} \mathrm{O} \times 285.83 \mathrm{~J} / \mathrm{mol}\right)\right)
\end{aligned}
$$




$$
\begin{gathered}
\Delta H^{o}=223.95 \mathrm{~J} \\
\Delta S^{o}=\sum n S^{o} \text { products }-\sum m S^{o} \text { reactacts } \\
\Delta S^{o}=\mid(1 \mathrm{~mol} \mathrm{NaOH} \times 48.1 \mathrm{~J} / \mathrm{mol} \cdot \mathrm{K})+\left(1 \mathrm{~mol} \mathrm{H}_{2} \times 130.7 \mathrm{~J} / \mathrm{mol} \cdot \mathrm{K}\right) \\
+\left(1 \mathrm{~mol} \mathrm{Cl}{ }_{2} \times 223.08 \mathrm{~J} / \mathrm{mol} \cdot \mathrm{K}\right) \mid \\
-\left|\left(1 \mathrm{~mol} \mathrm{H} \mathrm{H}_{2} \mathrm{O} \times 69.95 \mathrm{~J} / \mathrm{mol} \cdot \mathrm{K}\right)+(1 \mathrm{~mol} \mathrm{NaCl} \times 115.5 \mathrm{~J} / \mathrm{mol} \cdot \mathrm{K})\right| \\
\Delta S^{o}=216.43 \mathrm{~J} / \mathrm{K} \\
T_{K}=25^{\circ} \mathrm{C}+273.15=298.15 \mathrm{~K}
\end{gathered}
$$

But $\Delta G^{0}=\Delta H^{0}-T \Delta S^{0}$

$$
\begin{aligned}
\Delta G^{0} & =223.95 \mathrm{~kJ}-|216.43 \mathrm{~J} / \mathrm{K} \times 298.15 \mathrm{~K}| \\
& =-64304.65 \text { Joules }
\end{aligned}
$$

\section{Appendix 3. Highlight}

- Common ion effect influences ionic strength of electrolytes of the process.

- In the presence of a second source of $\mathrm{Na}^{+}$, salt becomes less soluble one of its constituent ions is already present in the solution. The source was obtained from the addition of soda ash in the process which increased the yield of the desired product.

- Thermodynamics and kinetics of the process could enhance the scale-up design process of the manufacturing equipment for caustic soda production. 